\title{
The Emergence
}

\section{of Whitefly-Transmitted Geminiviruses in Tomato in the Western Hemisphere}

\author{
Jane E. Polston \\ University of Florida, Bradenton \\ Pamela K. Anderson \\ Centro International de Agricultura Tropical, Cali, Colombia
}

$\mathbf{M}$ uch of the American subtropics and tropics have a climate that is conducive to the year-round production of tomato, Lycopersicon esculentum Mill. The tomato has been grown for centuries in the Americas, with the center of origin believed to be in northern South America. Processing tomatoes are produced throughout the tropics for local consumption and for conversion into paste. The production of fresh-market tomatoes is potentially a much more profitable business. The last few decades have seen an increase in the production of this type of tomato, both for export to northern countries during the Northern Hemisphere's winter season and to meet increases in demand from expanding local tourist industries.

Until the early 1990s, geminiviruses transmitted by whiteflies (Bemisia tabaci Genn.) were primarily a problem for legume production in the Western Hemisphere. There were only scattered reports of geminiviruses causing problems for tomato producers. The picture is quite different now. Since the late 1980s, most of the tomato-producing areas of Florida, the Caribbean, Mexico, Central America, Venezuela, and Brazil have suffered from

Dr. Polston's address is: University of Florida, Gulf Coast Research and Education Center, 5007 60th St. E., Bradenton, FL 34203

E-mail: jep@nersp.nerdc.ufl.edu

Dr. Anderson's address is: Centro International de Agricultura Tropical, Apartado 6713, Cali, Colombia

E-mail: p.anderson@cgnet.com

Publication no. D-1997-1028-01F

(C) 1997 The American Phytopathological Society high incidences of whitefly-borne geminiviruses, with devastating economic consequences for their respective tomato industries.

The whitefly-transmitted geminiviruses have thus become a major group of pathogens of vegetables in the subtropics and tropics of the Western Hemisphere. In addition to tomato, crops such as cucurbits and beans are also affected by these viruses. The genomes of these geminiviruses are composed of circular, single-stranded DNA, encapsidated by multiple subunits of a single capsid protein. Most are bipartite, having two almost equally sized genomic components, designated $\mathrm{A}$ and $\mathrm{B}$, separately encapsidated in geminate particles. At least one is monopartite, having a single, somewhat larger DNA component.

The family Geminiviridae is divided into three genera based upon the vector and plant host. Tomatoes are infected primarily by bipartite geminiviruses of the genus Begomovirus (previously known as subgroup III) in the Americas. However, in 1994, a monopartite geminivirus, tomato yellow leaf curl virus (TYLCV), was identified from tomato in the Caribbean $(60,68)$. TYLCV and the bipartite geminiviruses are transmitted by the whitefly B. tabaci, of which one biotype, $\mathrm{B}$, is also known as Bemisia argentifolii Bellows \& Perring (65). Although there is controversy regarding the taxonomy of the vector (14), different biotypes or species of whiteflies in this complex have shown little to no specificity for transmission of different geminiviruses (6). These viruses are believed to be transmitted in a persistent, circulative manner by the whitefly.

In the mid-1980s, a new whitefly biotype or species, which avidly fed and re- produced more successfully on tomato than most of the local biotypes, was introduced into the Western Hemisphere (90). This whitefly spread throughout the hemisphere and, in 1997, is still invading new areas, principally in South America. The appearance of this whitefly in tomato has been followed, within 2 to 5 years, by the appearance of one or more previously unreported geminiviruses. The purpose of this review is to document this increase, to document the impact of these viruses on the tomato industry in the Western Hemisphere, to briefly describe some of the geminiviruses, and to discuss the possible reasons for the appearance of these viruses in the Americas at this time.

\section{Economic Impact}

While no formal crop loss assessment studies have been undertaken for the tomato diseases caused by geminiviruses, the empirical data are impressive. The most

Table 1. Damage to tomato crops caused by geminiviruses in the Dominican Republic, 1988 to $1995^{\text {a }}$

\begin{tabular}{lcc}
\hline $\begin{array}{l}\text { Production } \\
\text { season }\end{array}$ & $\begin{array}{c}\text { Damage }^{\text {b }} \\
\text { Azua (\%) }\end{array}$ & $\begin{array}{c}\text { Damage } \\
\text { NW (\%) }\end{array}$ \\
\hline $1988-1989$ & $20-25$ & 5 \\
$1989-1990$ & $40-45$ & $5-10$ \\
$1990-1991$ & $35-40$ & $10-15$ \\
$1991-1992$ & $25-30$ & 15 \\
$1992-1993$ & $75-80$ & 80 \\
$1993-1994$ & $90-95$ & 50 \\
$1994-1995$ & 20 & 15 \\
\hline a Data from Alvarez and Abud-Antún, \\
1995 (3). \\
b Damage is defined as loss of crop \\
quality and quantity.
\end{tabular}


complete data set comes from the Dominican Republic. In 1988, multiple geminiviruses began to affect tomato production in the south central (Azua) and the northnorthwestern zones of the country. Crop damage from 1988 to 1995 ranged from 5 to $95 \%$ (Table 1). Economic losses in 1988 were estimated at $\$ 10$ million, with losses from 1989 to 1995 totaling an estimated $\$ 50$ million (3).

Data from the United States and other countries in the Americas are less complete, but the same pattern of devastating epidemics and losses emerges (Table 2). Diseases caused by geminiviruses are repeatedly referred to as the limiting biotic constraint to tomato production in the tropical Americas. In some countries (e.g., Nicaragua), entire zones have gone out of tomato production due to one or more geminiviruses. In Venezuela, the area of tomato production was reduced by $50 \%$ due to yield losses caused by tomato yellow mosaic virus (85). In Florida, disease caused by tomato mottle virus (ToMoV) was found in all tomato production areas of Florida, with reported incidences as high as $95 \%(69,73)$. ToMoV was conservatively estimated to have reduced the value of the 1990 to 1991 Florida tomato crop by $20 \%$ or $\$ 140$ million (89). From 1989 to 1995 , Puerto Rico suffered an estimated $\$ 40$ million in losses due to whiteflies, of which a significant portion was attributed to losses in tomatoes from whitefly-transmitted geminiviruses (9). Tomato producers in the Comayagua Valley of Honduras lost an estimated \$4.6 million in 1992 due to diseases caused by geminiviruses (21).

\section{Etiology}

More than 22 viruses outside the Geminiviridae and approximately 17 viruses within the Geminiviridae are reported to infect tomato in the Americas. Symptoms of geminivirus infection in tomato can resemble those induced by other viruses, especially those in the Potyviridae and Tobamoviridae. Symptoms of geminivirus infection vary with virus and strain, cultivar, plant age at the time of infection, and environmental conditions. Symptoms can include the following in various combinations: a bright yellow mosaic, chlorotic mottle, chlorotic leaf margins, leaf rolling, leaf distortion, puckering of leaves, reduction in leaf size, stunting of the infected plant, and flower abscission. Therefore, accurate diagnoses depend on the use of diagnostic assays.

Several assays have been developed to detect geminiviruses in tomato. One of the simplest and most accurate is the inclusion body visualization assay (25). Geminiviruses produce large nuclear inclusions, which stain blue with Azure A. These inclusions, which are characteristic for geminiviruses, can be seen with a light microscope. Tomato tissue is relatively easy to process, and numerous inclusions are produced in infected leaf and flower tissues. Polyclonal and monoclonal antibodies against the coat protein of several geminiviruses have been produced for use in assays to detect and distinguish geminiviruses $(24,41)$. Antibody selection can determine the specificity of the assay and can be tailored to detect a wide range of geminiviruses or to distinguish geminiviruses and their strains. In spite of the economic importance of these viruses, there are limited commercial sources of antibodies available for geminivirus detection. Other commonly used assays detect the nucleic acid of geminiviruses rather than their coat protein. Dot spot and squash blot hybridization assays rely on the use of a cloned viral DNA labeled with a reporter (i.e., ${ }^{32} \mathrm{P}$, biotin, digoxigenin) that is hybridized to target viral DNA fixed to a membrane $(38,73)$. Specificity of these assays can be controlled through the selec- tion of probe DNA and the hybridization and washing conditions. The most recent assay developed for detection of geminiviruses is polymerase chain amplification reaction (PCR). This assay uses only small amounts of either dried, fresh, or frozen tissue and is extremely sensitive for the detection of geminiviruses. Specificity of the assay can be controlled through the selection of primers and the conditions of the amplification (82). Some commercial companies offer testing services using this approach.

Geminiviruses are identified and distinguished primarily through the genomic sequence. The lack of consensus on a method for distinction of strains from isolates, and strains from species, has led to some confusion regarding the taxonomic status of new virus sequences. It is clear that partial sequences from particular genomic regions can be sufficient to establish relatedness and uniqueness. There are several regions of the genome that are of particular interest to taxonomists: the common region or intergenic region, the coat protein, and the replicase-associated protein $(63,84)$. It has been proposed that two isolates with greater than $90 \%$ homology of the coat protein amino acid sequence could be considered the same species (63). For many of the tomato-infecting geminiviruses, little to no biological characterization has been conducted. The paucity of biological data adds to the difficulty in establishing taxonomic distinctions. As more sequences are obtained and more biological characteristics are established, the taxonomic status of many geminiviruses will become clearer.

Because most of the viruses described in this report have been recognized in tomato within the last 10 years, characterization and even documentation are lacking for many. The geminiviruses presented in Table 3 represent most of those known to infect tomato in the Western Hemisphere and characterized to some extent.

\section{Distribution and Expansion}

Background. The first report of a geminivirus-induced disease in tomato occurred in the early 1960s in Brazil, when 30 to $40 \%$ of the tomato crop was affected with "infectious chlorosis" (34). The causal virus was subsequently identified as tomato golden mosaic virus (TGMV) (55). At approximately the same time, tomato yellow mosaic virus (TYMV) was reported in tomato throughout Venezuela and was viewed as a limiting factor for tomato production in the Venezuelan states of Aragua, Carabobo, Guarico, and Lara (30). In 1961, an epidemic forced many producers in Venezuela to eliminate their tomato plantings and replant. During a subsequent survey of tomato viruses in Aragua and Lara, TYMV was identified as the most prevalent virus in tomatoes (52). In Mexico in 
Table 3. Selected characteristics of geminiviruses that infect tomato in the Western Hemisphere

\begin{tabular}{|c|c|c|c|c|c|}
\hline Virus & Known distribution & Symptoms in tomato & $\begin{array}{l}\text { Hosts other than } \\
\text { tomato }^{\text {a }}\end{array}$ & $\begin{array}{l}\text { Most similar } \\
\text { sequence }^{\text {b }}\end{array}$ & References \\
\hline $\begin{array}{l}\text { Chino del tomate } \\
\text { (CdTV)/ Tomato leaf } \\
\text { crumple virus (TLCrV) }\end{array}$ & $\begin{array}{l}\text { Mexico (Chiapas, Morelos, } \\
\text { Sinaloa, Tamaulipas) }\end{array}$ & $\begin{array}{l}\text { Severe leaf curling, leaf } \\
\text { rolling, vein thickening, } \\
\text { yellow mosaic, stunting, } \\
\text { reduced fruit set }\end{array}$ & $\begin{array}{l}\text { Exp: Host range in- } \\
\text { cludes } 19 \text { species in } 4 \\
\text { families, Field: not } \\
\text { reported }\end{array}$ & $\begin{array}{l}\text { Sida mosaic } \\
\text { virus, Abutilon } \\
\text { mosaic virus }\end{array}$ & $17,64,97$ \\
\hline $\begin{array}{l}\text { Pepper huasteco virus } \\
\text { (PHV) }\end{array}$ & $\begin{array}{l}\text { Mexico (Guanajuato, } \\
\text { Quintana Roo, Sinaloa, } \\
\text { Tamaulipas), U.S. (Texas) }\end{array}$ & $\begin{array}{l}\text { Vein clearing, mild leaf } \\
\text { distortion, chlorosis, } \\
\text { stunting }\end{array}$ & $\begin{array}{l}\text { Exp.: Capsicum annuиm, } \\
\text { Field: C. annuиm }\end{array}$ & Unique & $\begin{array}{l}\text { 50,97,98; } \\
\text { R. Rivera-Busta- } \\
\text { mante, pers. comm. }\end{array}$ \\
\hline $\begin{array}{l}\text { Potato yellow mosaic } \\
\text { virus (PYMV) }\end{array}$ & $\begin{array}{l}\text { Guadeloupe, Martinique, Puerto } \\
\text { Rico, Trinidad, Tobago, } \\
\text { Venezuela }\end{array}$ & $\begin{array}{l}\text { Chlorotic mottle, leaf } \\
\text { rolling, leaf distortion }\end{array}$ & $\begin{array}{l}\text { Exp.: Species of Datura, } \\
\text { Petunia, Nicotiana, Field: } \\
\text { Solanum tuberosum }\end{array}$ & $\begin{array}{l}\text { Sida mosaic } \\
\text { virus, Abutilon } \\
\text { mosaic virus }\end{array}$ & $\begin{array}{l}\text { 27,43,45,66,80,81; } \\
\text { C. Fauquet, pers. } \\
\text { comm.; J. E. } \\
\text { Polston, unpub. }\end{array}$ \\
\hline $\begin{array}{l}\text { Serrano golden mosaic } \\
\text { virus (SGMV) }\end{array}$ & $\begin{array}{l}\text { Mexico (Sinaloa), } \\
\text { U.S. (Arizona) }\end{array}$ & $\begin{array}{l}\text { Leaf curling, leaf } \\
\text { distortion, stunting }\end{array}$ & $\begin{array}{l}\text { Exp.: C.. annuиm, C. } \\
\text { frutescens, Datura } \\
\text { stramonium, Field: } C . . \\
\text { annuum, C. frutescens }\end{array}$ & $\begin{array}{l}\text { Sequence not } \\
\text { reported }\end{array}$ & 18 \\
\hline $\begin{array}{l}\text { Sinaloa tomato leaf curl } \\
\text { virus (STLCV) }\end{array}$ & Mexico (Sinaloa) & $\begin{array}{l}\text { Foliar chlorosis and } \\
\text { purpling, leaf curling, } \\
\text { shortened internodes }\end{array}$ & $\begin{array}{l}\text { Exp.: C. annuиm, } \\
\text { Nicotiana tabacum, } \\
\text { Solanum melongena, } \\
\text { Malva parviflora, } \\
\text { Field: not reported }\end{array}$ & $\begin{array}{l}\text { Sequence not } \\
\text { reported }\end{array}$ & 15 \\
\hline $\begin{array}{l}\text { Taino tomato mottle } \\
\text { virus (TTMoV) }\end{array}$ & Cuba & $\begin{array}{l}\text { Rugosity, leaf } \\
\text { deformation and } \\
\text { curling, stunting }\end{array}$ & $\begin{array}{l}\text { Exp.: C. annuиm, } \\
\text { Field: not reported }\end{array}$ & $\begin{array}{l}\text { Sida mosaic } \\
\text { virus, Abutilon } \\
\text { mosaic virus }\end{array}$ & $\begin{array}{l}\text { 75; R. Rivera- } \\
\text { Bustamante, pers. } \\
\text { comm. }\end{array}$ \\
\hline $\begin{array}{l}\text { Texas pepper virus } \\
\text { (TPV)/Pepper jalapeno } \\
\text { virus (PJV) }\end{array}$ & $\begin{array}{l}\text { Mexico (Coahuila, Sinaloa, } \\
\text { Tamaulipas), Guatemala, } \\
\text { U.S. (Arizona, Texas) }\end{array}$ & $\begin{array}{l}\text { Mosaic, leaf curling, } \\
\text { stunting }\end{array}$ & $\begin{array}{l}\text { Exp.: C. annuиm, C. } \\
\text { frutescens, D. stramon- } \\
\text { ium, } 4 \text { Nicotiana spp., } \\
\text { Physalis wrightii, } \\
\text { Field: } C \text {. annuum, C. } \\
\text { frutescens, N. glauca }\end{array}$ & Unique & $88,97,98$ \\
\hline $\begin{array}{l}\text { Tomato geminivirus } \\
\text { BZ-Ub }\end{array}$ & Brazil (Minas Gerais) & Yellow mosaic & Not reported & $\begin{array}{l}\text { Bean golden mo- } \\
\text { saic virus-BZ, } \\
\text { tomato golden } \\
\text { mosaic virus }\end{array}$ & 76,102 \\
\hline $\begin{array}{l}\text { Tomato geminivirus } \\
\text { BZ-Ig }\end{array}$ & Brazil (Minas Gerais) & Yellow mosaic & Not reported & $\begin{array}{l}\text { Bean golden mo- } \\
\text { saic virus-BZ, } \\
\text { tomato golden } \\
\text { mosaic virus }\end{array}$ & 76,102 \\
\hline $\begin{array}{l}\text { Tomato golden mosaic } \\
\text { virus (TGMV) }\end{array}$ & Brazil & Yellow mosaic & $\begin{array}{l}\text { Exp.: D. stramonium, } 5 \\
\text { Nicotiana } \text { spp., Physalis } \\
\text { sp., Field: not reported }\end{array}$ & $\begin{array}{l}\text { Bean golden } \\
\text { mosaic virus- } \\
\text { BZ }\end{array}$ & $44,45,55$ \\
\hline $\begin{array}{l}\text { Tomato mottle } \\
\text { (ToMoV) }\end{array}$ & $\begin{array}{l}\text { Puerto Rico, U.S. (Florida, } \\
\text { occasional in: So. Carolina, } \\
\text { Tennessee, Virginia) }\end{array}$ & $\begin{array}{l}\text { Chlorotic mottle, leaf } \\
\text { curling, plant stunting, } \\
\text { reduced fruit size and } \\
\text { number }\end{array}$ & $\begin{array}{l}\text { Exp.: Lycopersicon spp., } \\
\text { Phaseolus vulgaris, } \\
\text { Field: Solanum viarum }\end{array}$ & $\begin{array}{l}\text { Sida mosaic } \\
\text { virus, Abutilon } \\
\text { mosaic virus }\end{array}$ & $1,13,57,67,71$ \\
\hline $\begin{array}{l}\text { Tomato yellow leaf curl } \\
\text { (TYLCV) }\end{array}$ & $\begin{array}{l}\text { Cuba, Dominican Republic, } \\
\text { Jamaica }\end{array}$ & $\begin{array}{l}\text { Reduced leaf size, } \\
\text { chlorotic margins, } \\
\text { chlorotic mottling, } \\
\text { flower abscission, } \\
\text { severe plant stunting }\end{array}$ & $\begin{array}{l}\text { Exp: Host range includes } \\
\text { species in approx. } 10 \\
\text { families, Field: Boerha- } \\
\text { via erecta, Cynanchum } \\
\text { acutum, D. stramonium, } \\
\text { and others }\end{array}$ & $\begin{array}{l}\text { Identical to } \\
\text { TYLCV-Is re- } \\
\text { ported in eastern } \\
\text { Mediterranean }\end{array}$ & $42,56,60,68,74,93$ \\
\hline $\begin{array}{l}\text { Tomato yellow mosaic } \\
\text { (TYMV) }\end{array}$ & Venezuela & $\begin{array}{l}\text { Yellow mosaic, leaf } \\
\text { curling, stunting }\end{array}$ & $\begin{array}{l}\text { Exp.: D. stramonium, } 2 \\
\text { Lycopersicon spp., Ni- } \\
\text { candra physaloides, } N \text {. } \\
\text { tabacum, Petunia hy- } \\
\text { brida, Physalis peruvi- } \\
\text { ana, Field: not reported }\end{array}$ & $\begin{array}{l}\text { Sequence not } \\
\text { reported }\end{array}$ & 52,99 \\
\hline $\begin{array}{l}\text { Tomato yellow mottle } \\
\text { (ToYMoV) }\end{array}$ & Costa Rica & $\begin{array}{l}\text { Chlorotic mottle, leaf } \\
\text { distortion, leaf curling, } \\
\text { stunting }\end{array}$ & Not reported & $\begin{array}{l}\text { Sequence not } \\
\text { reported }\end{array}$ & $46,47,59$ \\
\hline $\begin{array}{l}\text { Tomato yellow vein } \\
\text { streak virus (ToYVSV) }\end{array}$ & Brazil (São Paulo) & $\begin{array}{l}\text { Yellow mosaic, wavy } \\
\text { leaves }\end{array}$ & $\begin{array}{l}\text { Exp: Solanum tuberosum, } \\
\text { Field: not reported }\end{array}$ & Unique & 32 \\
\hline Tom GV1 & $\begin{array}{l}\text { Guatemala, Honduras, } \\
\text { Nicaragua }\end{array}$ & $\begin{array}{l}\text { Severe leaf curling,light } \\
\text { leaf mottling or chlorosis }\end{array}$ & Not reported & $\begin{array}{l}\text { Sequence not } \\
\text { reported }\end{array}$ & $\begin{array}{l}\text { 61; P. K. Anderson, } \\
\text { unpub. }\end{array}$ \\
\hline
\end{tabular}

${ }^{a}$ Hosts reported from either mechanical, whitefly, or biolistic inoculation experiments (Exp.) and from field collected samples (Field).

${ }^{b}$ Sequence comparisons based on coat protein nucleic acid sequences, or as reported by authors. 


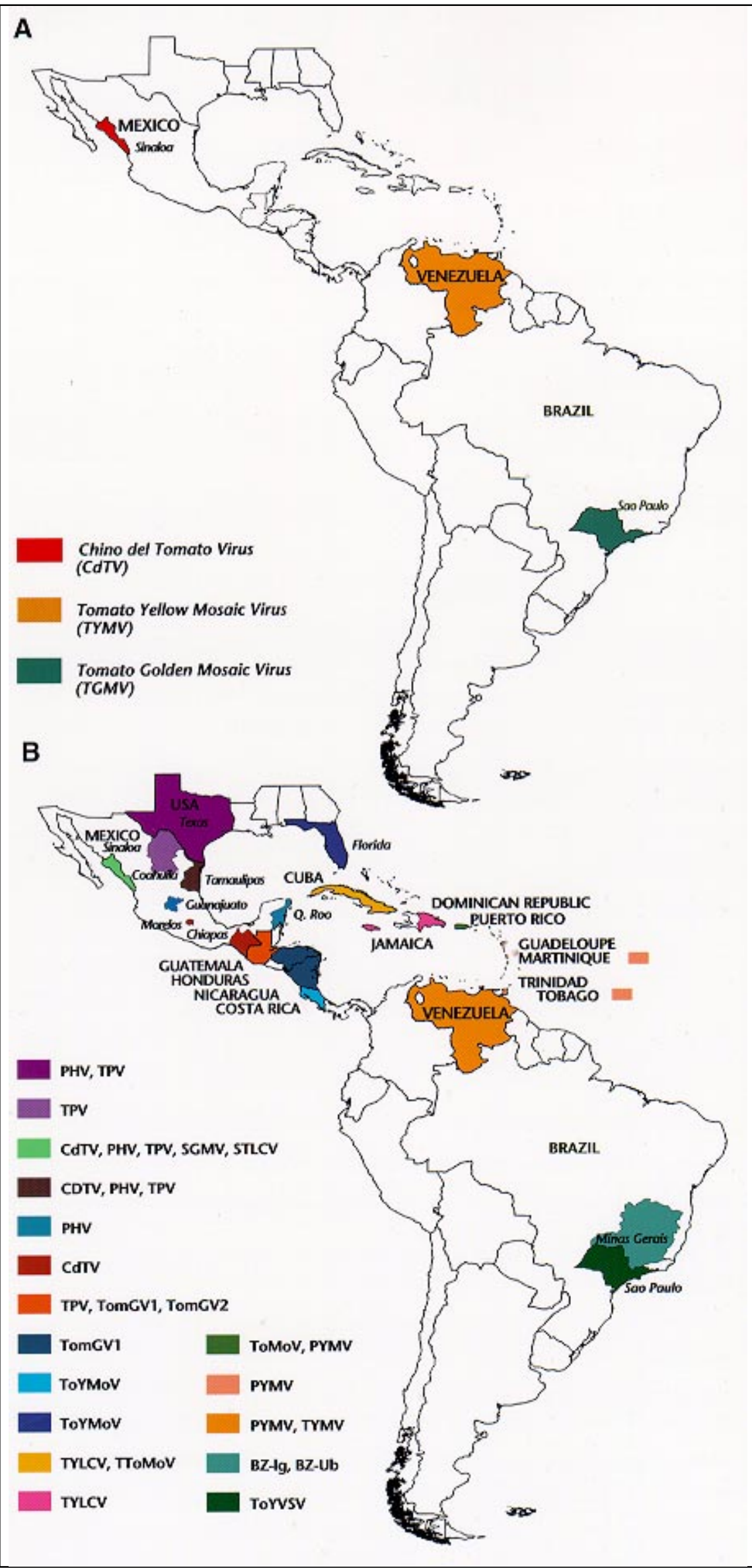

Fig. 1. (A) Known distribution of geminivirus epidemics in tomato in the Americas in the early 1970s. (B) Known distribution of geminivirus epidemics in tomato in the Americas in the mid-1990s. Data compiled May 1997.
1970 to 1971 , a virus now known to be the chino del tomate virus (CdTV) was reported infecting tomatoes on the west coast of Sinaloa $(17,36)$. TGMV, TYMV, and CdTV remained the only tomato-infecting geminiviruses reported from the Americas (Fig. 1A) until the mid to late 1980s, when geminivirus epidemics in tomatoes began to emerge throughout the tropical Americas (Fig. 1B).

It is now recognized that significant biological differences exist among populations of $B$. tabaci from different locations $(6,14,19)$. Although specific data are unavailable for most countries in the Western Hemisphere, it is apparent that until the mid-1980s, many of the $B$. tabaci biotypes fed and reproduced on tomato to only a limited extent, minimizing transmission of geminiviruses to and from tomato plants. In the mid-1980s, however, a new whitefly biotype or species was introduced into the Western Hemisphere from the Mediterranean, possibly through movement of infested ornamental plants. Although this whitefly was morphologically indistinguishable from the existing B. tabaci biotypes, there were significant biological differences. One was that the new whitefly fed readily and reproduced abundantly on tomato (90). This new whitefly was designated the $\mathrm{B}$ biotype to distinguish it from the B. tabaci A biotype, which was present in the southwestern United States before the introduction of the B biotype (14).

After its introduction, the B biotype is believed to have spread within the Western Hemisphere through the movement of ornamental plants (14). By the late 1980s, the $B$ biotype had established and displaced the indigenous populations of $B$. tabaci in Texas and Florida (14,90). By 1990, the same had occurred in Arizona and California. The B biotype was subsequently identified from Antigua, Barbuda, the Dominican Republic, Grenada, Guadeloupe, Puerto Rico, Trinidad and Tobago, St. Kitts and Nevis, and Mexico (state of Quintana Roo) by 1990 or 1991 (12); by 1992, it was found in western Mexico (Sonora), Belize, and Nicaragua (11); by 1993, it was found throughout most of Central America and had moved into Brazil (14); and by 1994, it was found throughout Venezuela and was moving south along the west coast of Mexico into Sinaloa and Tamaulipas (12). The $\mathrm{B}$ biotype has just been identified in Colombia (C. Cardona, CIAT, Cali, Colombia, personal communication).

The following scenario has been repeated in many locations. Large populations of whiteflies are observed in tomato, followed by irregular ripening of the fruit due to the phytotoxicity of the saliva of immature whiteflies (90). Pesticide use increases dramatically. Growers struggle with the high whitefly populations, without much success. Within 2 to 5 years, viruslike symptoms appear in tomato plants, first at low incidence but quickly increas- 
ing to epidemic levels. Yields are sometimes reduced to almost nothing, and tomato fields in production may be abandoned. Because the price of tomatoes increases due to scarcity, some growers attempt to produce tomatoes with very frequent applications of highly toxic insecticides. However, tomato yields continue to decline.

\section{Case Histories}

Following is a summary of the history of selected geminiviruses chosen to illustrate the development, proliferation, and complexity of this group of pathogens. The viruses are arranged by geographical location, starting with the United States (Florida), followed by Mexico, Central America, South America, and the Caribbean.

Tomato geminiviruses in the United States. Geminiviruses were not known as a problem in Florida's agricultural production until the appearance of tomato mottle virus (ToMoV) in tomatoes in 1989 (51). Agricultural production in Florida has been closely monitored for more than 40 years, so it is unlikely that geminivirus disease outbreaks had been overlooked. B. tabaci had been present in the state since at least the late 1800s. The existence of several weeds with golden mosaic symptoms was known since the 1950s, and their recognition as geminivirus hosts has been known since the early 1980 s (45). High populations of whiteflies, later identified as $B$. tabaci B biotype, were first noticed in tomatoes in the field in 1987 (90). Tomato plants with unusual viruslike symptoms were first seen at low incidences in southwestern Florida in the spring crop of 1989, and high incidences were observed for the first time in the fall crop of 1989 (Fig. 2) (51). Within a few months, the cause of the disease was identified as a whitefly-transmitted geminivirus, and within a year, the virus had been sequenced and found to be unique (1). Studies were conducted on the host range, although no significant weed hosts were identified $(57,71)$. Incidences of ToMoV-infected plants in some fields ranged as high as $100 \%$ at the close of many growing seasons $(69,73)$. High incidences occurred despite frequent foliar applications of insecticides, as often as seven times per week. Since 1994, growers have used imidacloprid, a systemic insecticide, which has resulted in low incidences of ToMoV (70).

The origin of ToMoV is believed to be Florida; however, ToMoV has also been found in a few plants in Virginia, in epidemics in South Carolina and Tennessee, and has become endemic in Puerto Rico $(13,45,67)$. These occurrences may be the result of movement of ToMoV-infected tomato transplants from Florida.

Epidemics caused by Texas pepper virus (TPV) were first observed in tomato and pepper in Texas in 1987, and were associ- ated with high populations of B. tabaci B biotype (96). The epidemic lasted only a few years, and the virus has not occurred in epidemic proportions in tomato in Texas since that time. However, epidemics of this virus occur routinely in tomato and pepper in the state of Tamaulipas in northeastern Mexico (97).

Pepper huasteco virus (PHV) has been detected in peppers in the United States since 1987 (96). Like TPV, PHV is capable of infecting tomato and has been detected in tomatoes in Mexico (97). Presumably, these viruses can be found in tomato in Texas, although there are few reports of epidemics. One epidemic of a geminivirus, which may have been TPV or PHV, occurred in the spring of 1997 in greenhouse tomatoes near Davis, Texas (J. E. Polston, unpublished). A similar situation exists in Arizona, where TPV has been detected in pepper and Serrano golden mosaic virus (SGMV) has been detected in pepper and tomato (18). Although both viruses are capable of infecting tomato, no epidemics in tomato in Arizona have been reported. The reason for the absence of reported epidemics by PHV, TPV, and SGMV in tomato in the United States is unknown.

Tomato geminiviruses in Mexico. Symptoms caused by chino del tomate virus (CdTV) have been seen in tomato in the state of Sinaloa, northwestern Mexico, since $1970(17,36)$. Epidemics of this disease occurred there from 1976 to 1983, and annually since 1988 in conjunction with high populations of B. tabaci (17). Epidemics since 1990 are due in large part to the appearance of the B biotype of B.tabaci (97). Symptoms of CdTV are particularly severe in tomato compared with most other geminiviruses, and the host range is considered broad (Fig. 3) (17). In Sinaloa, the virus can be found readily in both pepper and tomato fields. A recent survey of pepper and tomato fields in Mexico found CdTV for the first time in the Mexican states of Chiapas, Morelos, and Tamaulipas (97). These results indicate that this virus now occurs in all tomato production areas of Mexico. It was suggested that this emergence may have been due to the movement of tomato transplants from $\mathrm{Si}$ naloa to other production areas. In this study, chino del tomate virus was found to co-occur with at least two other geminiviruses, PHV and TPV. This has complicated, not only detection and identification, but also disease management. Over the last few years, the frequency of detection of CdTV in Sinaloa has decreased, suggesting that it is being displaced by other geminiviruses.

Epidemics of TPV occur routinely in tomato and pepper in the state of Tamaulipas, in northeastern Mexico (97). A second virus associated with these epidemics is pepper jalapeno virus (PJV), which subsequently was found in tomato in Sinaloa and in pepper in other states in Mexico (97). This virus has recently been reclassified as a strain of TPV (97). The two strains vary
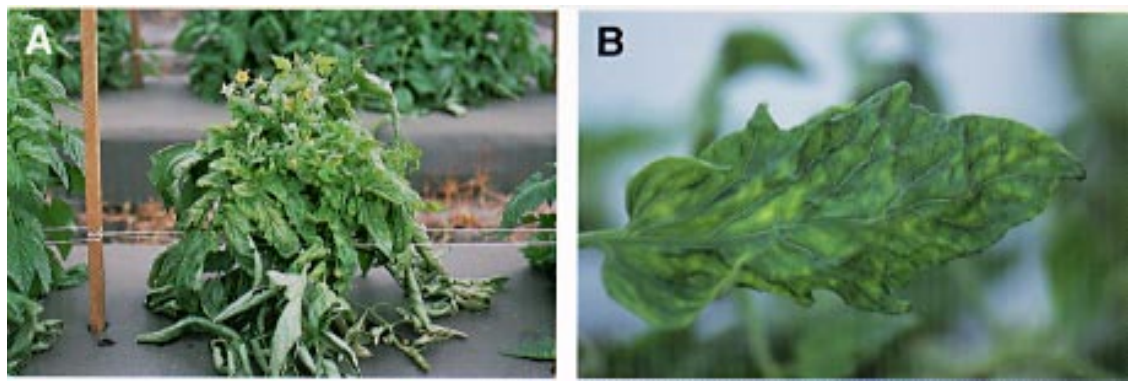

Fig. 2. Tomato plants infected with tomato mottle virus. (A) Early infection of cv. Sunny in a Florida tomato field showing leaf rolling, chlorotic mottling of leaves, and stunting of plant. (B) Close-up of a leaflet from an infected plant showing chlorotic mottling and leaf distortion.
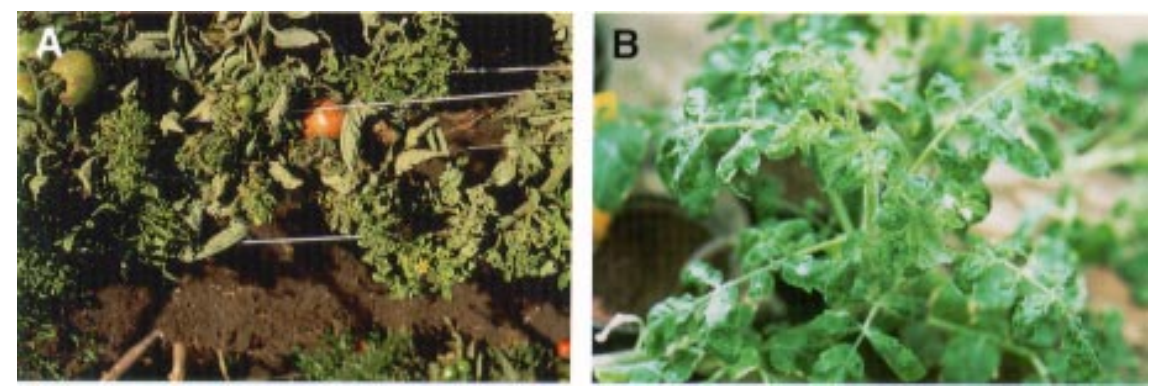

Fig. 3. Tomato plant infected with chino del tomate virus (CdTV) (A) Infected plant in the field in the state of Sinaloa (Mexico) showing severe leaf distortion, leaf cupping, and reduced leaf size as well as a severe reduction in plant height. Infected plant has few fruit. (B) Close-up of CdTV-infected plant inoculated in the greenhouse, showing leaf curling and distortion. (photos courtesy P. Himmel [A], and J. K. Brown [B]) 
in geographic distribution, symptom expression, and possibly in host range $(96,97)$. PHV is widely distributed throughout Mexico and has been detected in both pepper and tomato (97). A distinct strain of PHV was found in tomato in Sinaloa in $1990(50,97)$.

Several other geminiviruses have been reported to infect tomato in Mexico. These are Sinaloa tomato leaf curl virus (STLCV), SGMV, tomato leaf crumple virus (TLCrV), and the viruses causing rizado amarillo and tigre disease $(15,18,64,98)$. The relationship of these viruses to each other and the significance of each to tomato production in Mexico is only partially understood at this time. The tomato leaf crumple virus and CdTV appear to be strains of the same species $(64,97)$. SGMV, which also infects tomato and pepper in Sinaloa, appears to be closely related to TPV and PJV (18; J. K. Brown, University of Arizona, Tucson, personal communication). In at least one case, a tomato disease was shown to be the result of infection by two geminiviruses (37). To summarize, the geminiviruses that infect tomato in Mexico often occur in complexes with other geminiviruses, and the composition of these complexes varies among production seasons and locations. Over the next few years, as more geminivirus sequences are gathered and compared, our understanding of the geminivirus infections of tomato in Mexico will improve greatly.

Tomato geminiviruses in Central America. In Central America, a tomato disease believed to be caused by a whitefly-transmitted virus was first reported from the tomato-producing Sebaco Valley of Nicaragua in 1983 and 1984 (83). By mid-1986, the director of the Sebaco Valley Experiment Station reported that $100 \%$ of the tomatoes in the experimental plots were virus infected (P. K. Anderson, unpublished). Analysis of symptomatic tomato leaf tissue, using a nonradioactive nucleic acid blot hybridization assay, revealed the presence of a geminivirus (J. K. Brown and P. K. Anderson, unpublished). This is the first known detection of a geminivirus from tomatoes in Central America.

Subsequently, economically significant tomato diseases associated with $B$. tabaci were reported from Guatemala in 1987, El Salvador and Costa Rica in 1988, Honduras in 1989, and Panama in 1991 $(21,29,46,95,101)$. In 1989 , the second detection of a geminivirus from diseased tomatoes was reported from plants growing in the Central Valley of Costa Rica utilizing light and electron microscopy (59). Although geminiviruses are causing significant yield losses in tomato-producing zones throughout Central America (Table 3 ), less is known about these viruses compared with those from elsewhere in this hemisphere. TPV, identified from tomatoes in Guatemala (D. P. Maxwell, University of Wisconsin, Madison, personal communication), is the only previously characterized tomato geminivirus identified from the region to date. Additional geminiviruses with temporary designations have been identified in Guatemala (TomGV1, TomGV2), Honduras (TomGV1), and Nicaragua (TomGV1) (61; D. P. Maxwell, personal communication). TomGV1 appears to be related to squash leaf curl virus (61). At least one geminivirus has been found infecting tomato in Belize, but it is not clear how this geminivirus is related to TomGV1 and TomGV2 $(53,62)$. The tomato geminivirus from Costa Rica appears to be a distinct geminivirus and is now referred to as tomato yellow mottle virus (Fig. 4) (61; D. P. Maxwell, personal communication).

Tomato geminiviruses in South America. A disease later known to be caused by tomato yellow mosaic virus (TYMV) was first recognized in tomato production in Venezuela in the 1960s $(30,52,99)$. The virus produced a characteristic bright yellow mosaic in infected tomato and was regarded as a limiting factor in the production of tomato in Venezuela (52). In the mid-1970s, almost $100 \%$ of plants surveyed at flowering showed characteristic symptoms of TYMV (52) (Fig. 5). In 1990 to 1991, B. tabaci B biotype and irregular ripening were found for the first time in Venezuela tomato fields. In 1997, a strain of potato yellow mosaic virus (PYMV) was identified from affected tomatoes (43). The sequence of this virus was distinct from that of PYMV characterized from potato in the 1980 s (81). Interestingly, greenhouse tests reported in 1986 with PYMV isolated from potato revealed that tomato was a host. However, no natural infections of this virus in tomato had been reported (81). A second virus was also identified in tomato in the same areas where PYMV was found. It is not known what relationship these viruses have to TYMV.

The first recognition of a geminivirus as the cause of a whitefly-transmitted tomato disease in the Americas occurred with tomato golden mosaic virus (TGMV) in
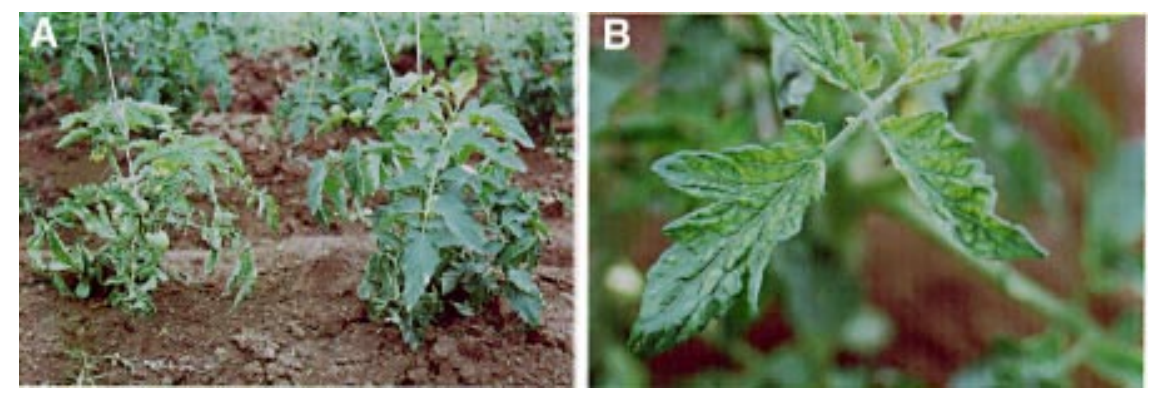

Fig. 4. (A) Tomato plant on the left is infected with tomato yellow mottle virus (ToYMoV) and the plant on the right in not infected in a field in Costa Rica. The infected plant shows the characteristic symptoms of ToYMoV infection of reduced plant height, reduced leaf size, and chlorotic mottling of leaves. (B) Close-up of leaf from infected plant showing chlorotic mottling of leaves and mild leaf distortion. (photos courtesy L. Hilje)
Brazil. TGMV was a problem in tomato production in Brazil as early as the 1960s (34). In 1975, TGMV was purified, and geminate particles were observed (55). TGMV was one of the first geminiviruses to be sequenced (44). Interestingly, recent surveys in Brazil have not found TGMV (8,76; F. M. Zerbini, Universidade Federal De Viçosa, MG, Brazil, personal communication).

Since 1994, a series of distinct tomato geminiviruses appear to be emerging in Brazil. Tomato geminiviruses have been detected wherever tomatoes are surveyed $(8,78,102$; F. M. Zerbini, personal communication). In the state of Minas Gerais, two distinct bipartite geminiviruses associated with yellow mosaic symptoms have been identified. Provisionally named TGV-BZIg and TGV-BZ-Ub, comparison of their sequences to those of others revealed distinct viruses, which were most closely related to bean golden mosaic virus from Brazil (type 1) and TGMV $(76,102)$. In the state of São Paulo, another geminivirus, tentatively named tomato yellow vein streak geminivirus (ToYVSV), has been detected (32). Preliminary work shows only $80 \%$ sequence similarity of ToYVSV to TGV-BZ-Ig and TGV-BZ-Ub (F. M. Zerbini, personal communication). Tomato geminiviruses have also been isolated from the states of Rio de Janeiro, Bahia, Pernambuco and in the Federal District $(77,78)$. Complete sequences of these viruses are not yet available, but preliminary results indicate that they are different from those previously described (I. C. Bezerra, EMBRAPA-CNPH, Brasilia, D.F.-Brazil, personal communication). Together, the states where tomato geminiviruses have been detected account for over $75 \%$ of the tomato production (both fresh market and processing) in Brazil.

The B biotype of B. tabaci was first observed in 1990 to 1991 in São Paulo, possibly introduced from Europe by the importation of ornamental plants (58). In 1993, it was observed in the Federal District in both cultivated and weed species (35). This whitefly biotype has also been reported in the states of São Paulo, Parana, 
Rio de Janeiro, Bahia, and Pernambuco. A good example of how this whitefly biotype is spreading in Brazil is the state of Pernambuco. Within months after it was first observed, the $\mathrm{B}$ biotype became widespread in melon, watermelon, and tomato crops (54). This biotype easily colonizes tomato, reaching high population levels even with competition from nearby plantings of cucurbits and soybeans (the traditionally preferred reproductive hosts of $B$. tabaci in Brazil).

Tomato geminiviruses in the Caribbean. High populations of $B$. tabaci biotype B have been present in the Dominican Republic since 1987 (94). In 1988, indigenous geminiviruses began to appear and affect tomato production in the south (Azua) and northwestern production areas (Table 1) $(3,16)$. Symptoms of what would later be recognized as tomato yellow leaf curl virus (TYLCV) were first noticed in the northwestern production region in 1992 (Fig. 6) (68). TYLCV was first described in 1964 from Israel, where it has remained the major limiting factor in tomato production (26). From discussions with tomato growers, it appears that TYLCV was unknowingly introduced by a tomato producer located in the northwestern region of the Dominican Republic. This grower was producing tomatoes in a greenhouse using a fresh-market greenhouse cultivar that was only available as transplants from Israel (J. E. Polston, unpublished). The virus was identified as TYLCV-Is in 1994 based on blot hybridization, PCR, and a partial genomic sequence $(60,68)$. TYLCV was subsequently identified in Jamaica and Cuba $(42,56,74)$. It is not yet clear whether these epidemics are the result of separate introductions or regional spread from a single introduction. Symptoms of TYLCV were reported to be present since 1987 in Cuba, although only since 1992 in the Dominican Republic $(68,74)$. TYLCV has been found in home gardens and in weed species, and it appears to have established in the agroecosystem of the Caribbean $(42,93)$.

TYLCV is the only known example of a geminivirus introduced from the Old World to the New World. All other gem- iniviruses in tomato in this hemisphere of which we know the sequence show originations in the New World.

The distribution of potato yellow mosaic virus (PYMV) in tomato appears to be widespread and may still be expanding. PYMV was first described in potato in 1986 from Venezuela $(27,81)$. In 1992, viruslike symptoms of chlorotic mottling, leaf distortion, and leaf rolling were seen for the first time in tomato in Martinique; and in 1993, they were seen for the first time in Guadeloupe (Fig. 7) $(48,49)$. Very quickly, high incidences of symptomatic plants could be found in tomato fields from both islands. The B biotype was observed in tomato on these two islands beginning around 1990. Sequence analysis revealed that a virus, which was closely related to PYMV from Venezuela, was associated with the symptoms in both islands (66). Geminivirus sequences from infected plants from Martinique and Guadeloupe were determined to be essentially identical. PYMV, with a sequence essentially identical to that from Martinique and Guadeloupe, was found in symptomatic tomatoes in Puerto Rico (66). A PYMV with a similar sequence has also been found in tomato in Trinidad and Tobago, where epidemics with high incidences of infected plants have occurred over the last several years (C. M. Fauquet, ILTAB/ORSTOM-TSRI, La Jolla, CA, personal communication).

B. tabaci biotype B and irregular ripening were recognized in Venezuela tomato fields in 1990-1991 followed by new viruslike symptoms within a few years (R. de Uzcátegui, Inst. de Investigaciones Científicas, Caracas, Venezuela, personal communication). In 1997, a virus similar in sequence to PYMV was identified from tomatoes with viruslike symptoms (43). A second virus of a different sequence was also identified in the same areas where PYMV was found. The relationship of these viruses to ToYMV is currently unknown.

It is not known how PYMV came to be distributed so widely and in so many locations in the eastern Caribbean, and moreover, with little genomic variation. It is pos-
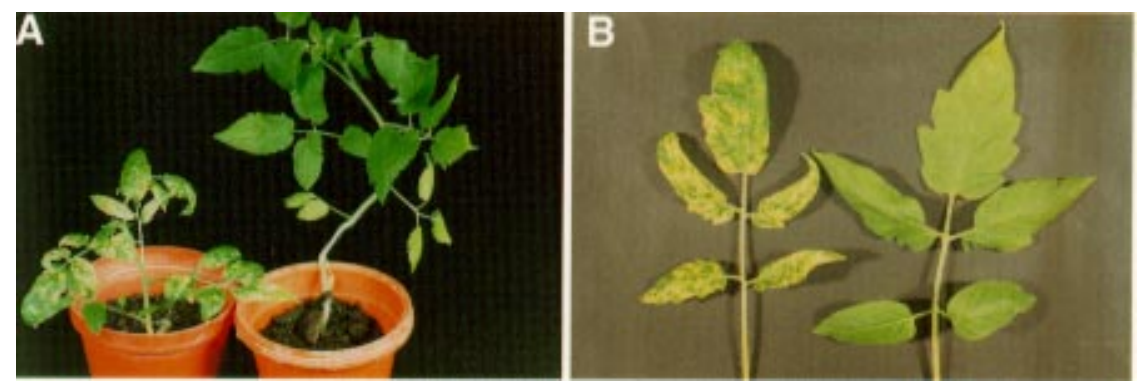

Fig. 5. (A) Rio Grande tomato plants inoculated in greenhouse studies with tomato yellow mosaic virus (TYMV) from Venezuela on the left, noninoculated plant on the right. Plant on the left shows characteristic symptoms of infection with TYMV, a golden mosaic of the leaves, reduction in plant height, and leaf cupping and distortion. (B) Close-up of leaves from above, leaf from infected plant on the left and leaf from noninoculated plant on the right. (photos courtesy R. C. de Uzcátegui) sible that the virus has been disseminated recently, either through the movement of infected tomato transplants or potato tubers, or through the movement of plant material harboring viruliferous whiteflies. It is also possible that viruliferous whiteflies were distributed by one or more of the hurricanes that occur between June and October every year.

\section{Ecology and Epidemiology}

The B biotype of $B$. tabaci is spreading throughout the Americas. Of epidemiologi-
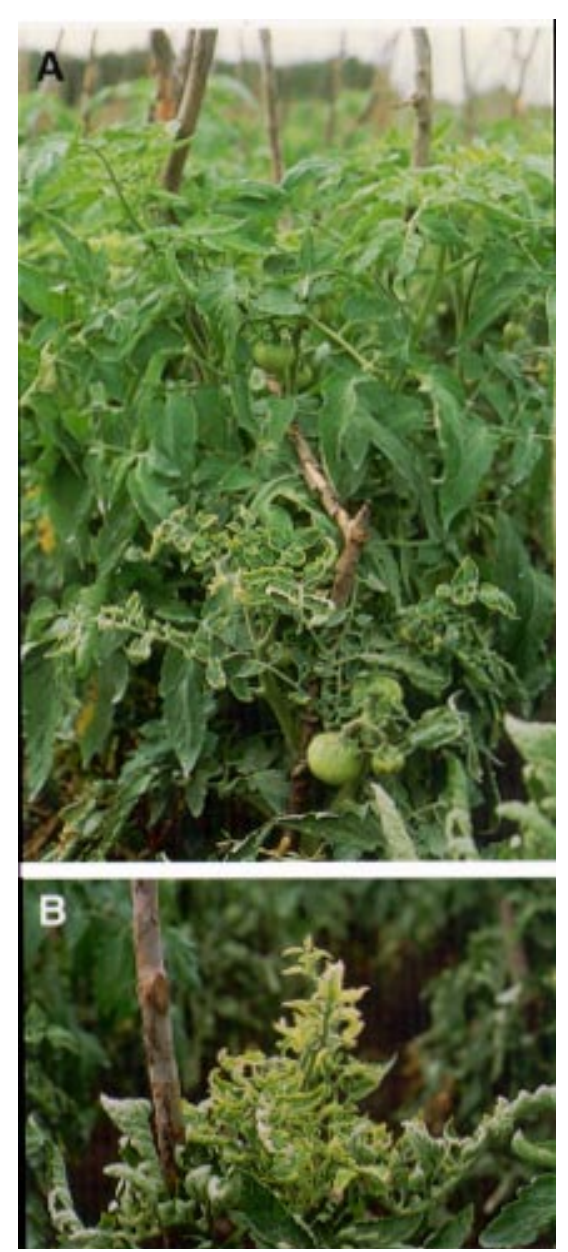

Fig. 6. Tomato plant infected with tomato yellow leaf curl virus (TYLCV) in front of a noninfected plant in Jamaica. (A) The plant in the foreground was probably infected with TYLCV at about the time of first flower, about 4 to 6 weeks after transplantation to the field. The plant shows the severe stunting, severe leaf deformation, reduced leaf size, and chlorotic mottling of leaves and leaf margins that are characteristic symptoms of this virus in tomato. Although this plant was able to set fruit on the first flowers due to the time of inoculation, no fruit was produced on subsequent flowers, due to the characteristic abscission of flowers caused by TYLCV. (B) TYLCV infection in an older plant shows a severe reduction in the internode length, producing a telescope effect. Leaves show severe distortion, chlorosis especially of the margins, and a severe reduction in size. 
cal significance are data indicating that the B biotype has a broader host range, higher fecundity, and possibly a greater dispersal capacity than at least one and probably other indigenous $B$. tabaci populations $(6,7,14,20)$. Comparisons with other indigenous whitefly biotypes have not been reported. While weeds play an important role in maintaining whiteflies in the agroecosystem, cultivated hosts are the most important source of whiteflies. Crop biomass provides breeding and feeding sites and gives rise to large populations of $B$. tabaci (19). Scarce reports of host preferences of indigenous biotypes indicated that tomato was not a good host for whitefly reproduction (33). During the past decade, however, B. tabaci has been observed colonizing and reproducing on previously marginal host plants such as tomato, peppers, eggplant, lettuce, and cabbage. Experimental data showed that the B biotype readily adapted to new host plants, while non-B populations exhibited high mortality on new hosts (6). B. tabaci B biotype females were shown to have significantly higher rates of oviposition on cotton than did the indigenous A biotype (7). Greater reproductive capacities, and an ability to colonize tomato, contribute to an increased capacity of the B biotype to vector tomato geminiviruses.

Host range information is not only valuable for virus characterization, but also has significant implications for the epidemiology and management of whiteflytransmitted geminiviruses. Various tomato geminiviruses can also infect beans (Phaseolus vulgaris L.), peppers (Capsicum annuum L., C. frutescens L.), potato (Solanum tuberosum L.), and tobacco

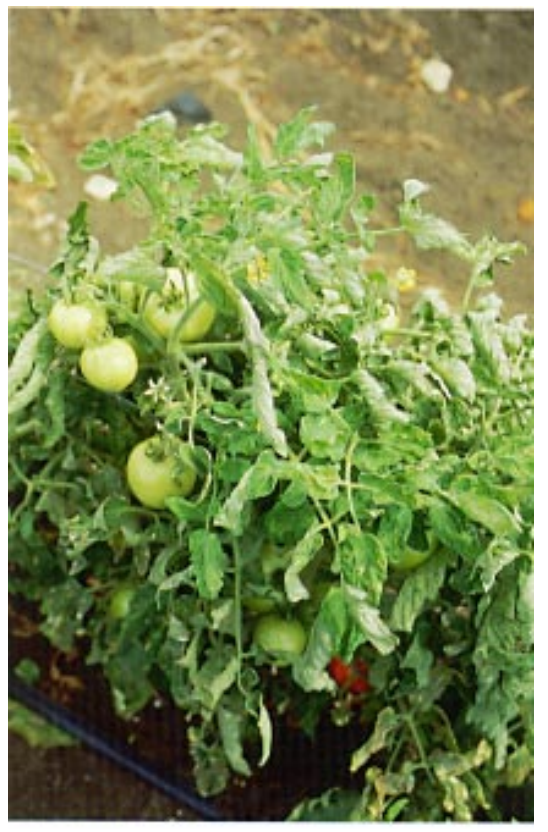

Fig. 7. Tomato plants infected with potato yellow mosaic virus in Guadeloupe. Typical symptoms of leaf distortion, leaf rolling, and chlorotic mottling are visible.
(Nicotiana tabacum L.) (17,18,26,32,57, $71,81,93,96,99)$. These plants are important food and cash crops throughout the Americas. For the most part, determinations of the host ranges of tomato geminiviruses have been conducted by inoculation studies in greenhouses. However, TPV, PHV, CdTV, SGMV, and STLCV have been detected in peppers in the field in Mexico; and PYMV has been detected in potatoes in the field in Venezuela. For the majority of these viruses, there are no reports of detection in alternate cultivated hosts.

Even fewer data exist on alternate, noncultivated hosts of tomato geminiviruses. In a survey for noncultivated hosts of ToMoV, 42 species in 14 families were tested from samples collected from west central and southwest Florida (57). All samples tested negative for ToMoV, except for Solanum viarum Dunal (Solanaceae); however, the importance of $S$. viarum in the epidemiology of ToMoV was concluded to be minimal due to the low rate of infection of $S$. viarum in the field and the difficulty of transmitting ToMoV from $S$. viarum to tomato. However, significant noncultivated host plant reservoirs have been identified for TYLCV in Israel (26). In the Dominican Republic and in Cuba, studies suggest that TYLCV may be present in several species of noncultivated plants $(42,93)$. Data on the weed hosts for many tomato geminivirus pathosystems are lacking.

Mathematical epidemiology on whiteflytransmitted geminivirus pathosystems is limited. Work is in progress to develop quantitative regional models and fieldbased (within-field spread) models, but none of the proposed models has been validated $(2,4)$. While information is growing on the identification and distribution of the geminiviruses infecting tomatoes in the Americas, critical data on the biology and ecology of the pathosystems lag behind. It is critical for management of these diseases that progress be made on the quantitative evaluations of the virus' pathosystems.

\section{Management}

Crop protection practices. Geminiviruses in tomato are difficult and expensive to manage. Regional management will undoubtedly be based on source reduction of whiteflies, and where possible, on reduction of virus inoculum. The study of natural hosts for ToMoV (57), elucidating the fact that tomato was the only significant virus host, led to inexpensive intervention recommendations (rapid crop removal), which would have been more effective if more growers had complied. In the Dominican Republic, whitefly host-free periods imposed by the government appear to have reduced the incidence of TYLCV in the early part of the tomato season in those areas where it was enforced. However, uneven enforcement of the ban is common and has impeded whitefly and disease management. For crop-oriented management, the two tactics most frequently implemented to protect crops from insect-transmitted viruses, including whitefly-transmitted geminiviruses, are insecticides and resistant crop varieties.

Insecticides are the most often employed and most expensive approach to geminivirus management. Several insecticides, oils, and soaps are used to reduce whitefly populations and incidence of infected plants both in transplant-production houses and in the field (91). In some places and seasons, the use of insecticides can reduce incidence of infected plants to economically satisfactory levels. However, under some circumstances, e.g., when there is a large source of viruliferous whiteflies nearby, insecticides have been less successful. In much of the tropical Americas, few effective insecticides are available due to insecticide resistance in the whitefly populations and, in the case of small growers, to their high cost. In many areas (e.g., Dominican Republic, Florida, and Mexico), geminivirus management is almost entirely dependent upon the use of insecticides. One relatively recently introduced insecticide, imidacloprid, has had a major impact over the last few years on whitefly populations and incidence of geminiviruses (70). Recently, resistance to imidacloprid has been reported from Spain (22). The efficacy of insecticides can be increased when different types are applied in rotation and in conjunction with regular scouting (91).

At present, no tomato cultivars with resistance to the vector are commercially available. Likewise, no tomato cultivars are available with immunity or even moderate tolerance to any of the geminiviruses that infect tomato, with the exception of TYLCV. Cultivars with TYLCV tolerance often do not perform as well against most other geminiviruses present in the Americas (92). Therefore, most of the tomatoes produced in the Americas are completely vulnerable to the indigenous geminivirus complexes. Several commercial and university breeding programs are attempting to develop resistance to tomato geminiviruses. Some inbred tomato lines reported to be tolerant to TYLCV have been evaluated in field assays and appear to be promising sources of resistance to geminiviruses in Brazil, Florida, and the Dominican Republic $(40,92)$. To date, two types of resistance have been found: first, resistance derived from several species of Lycopersicon, which is mostly multigenic; and second, several different genes from geminiviruses (pathogen-derived resistance), when transformed into plants, have been shown to be useful sources of resistance. In general, commercially available resistance to TYLCV can be overcome when moderate to high populations of viruliferous whiteflies are present and when plants are 
inoculated within the first few weeks in the field. Thus, vector management is an essential complement to the use of resistant cultivars at this time.

Several cultural and legal tactics pertaining to crop removal and crop-free periods have successfully decreased the incidence of geminivirus-infected plants. However, these practices do not appear to be sufficiently effective unless used in combination with insecticides or resistant cultivars. Whitefly host-free periods reduce whitefly populations and in some cases decrease the numbers of viruliferous vectors. Tomato transplants should be produced at least several miles from tomato fruit production areas. Row covers over young tomatoes can help delay the onset of infection. New fields of tomatoes should not be planted near or downwind from older fields. UV-reflective mulches have been shown to decrease the incidence of virus-infected tomato plants early in the season (28).

Economically viable management has not been achieved regularly in most areas where geminiviruses infect tomato. However, two production areas, Florida and the Dominican Republic, have achieved successful management for several years.

Management in Florida. Fresh-market tomatoes are produced primarily in large fields of plastic-mulched raised beds that support staked tomato plants. Planting is generally more synchronized than in the tropics, and production is not year-round. Only one geminivirus, ToMoV, is known. Since host-range and field studies concluded that old tomato crops and volunteers were the most important sources of ToMoV (57,71), tomato growers were encouraged to improve field sanitation at the end of the season and to maintain a tomato-free period between production seasons (73). Further, many growers stopped producing their own transplants and began to purchase their transplants from commercial producers who were not located near tomato fields. The most significant management tactic has been the use of a systemic insecticide, imidacloprid, which has efficacy against all life stages of the whitefly. Since 1994, this insecticide has been used as a soil drench on almost all tomatoes, both in the transplant production house and in the field. Most growers apply imidacloprid at the time of planting in the field at a rate that is effective for about 8 weeks, after which time they apply a rotation of different foliar insecticides. The incidence of ToMoV-infected plants was reduced the first season and continued to decline. Incidence continues to be very low 3 years later. This approach to virus management is expensive but effective for one virus with a relatively simple disease cycle in a context of relatively synchronized planting seasons.

Management in the Dominican Republic. Until the early 1990s, Dominican
Republic tomato production was characterized by both small and large producers of primarily processing tomatoes, which were planted year-round. Transplants were produced next to production fields, and expensive inputs such as plastic mulches and raised beds were not employed. After the arrival of the B biotype, several geminiviruses appeared in tomato, including TYLCV. Successful management of TYLCV is more difficult than management of many other geminiviruses. TYLCV is transmitted more readily than some other geminiviruses, and the virus has alternate hosts both in the weeds and in backyard gardens (93). A 3-month whitefly host-free period, enacted to reduce the populations of a geminivirus in bean, was continued in order to aid the tomato growers. Compliance was compulsory, but government enforcement was uneven. Economically successful management was achieved by large tomato growers in the Dominican Republic with the necessary financial resources. Some growers produce their transplants in an area removed from tomato production. Occasionally, growers are able to use fields that are isolated from other tomato production fields. Many growers are using TYLCV-tolerant cultivars, which are more expensive but which often produce an acceptable yield. Growers also rely upon several applications of imidacloprid throughout the season, beginning at transplant production. In addition, growers have reduced the length of their growing season to avoid high whitefly populations present in February and March. The effect of these changes in management practices can be seen in the decrease in damage caused by tomato geminiviruses beginning in 1994 (Table 1) (93).

In contrast to the success of the large growers, many of the small tomato growers in the Dominican Republic no longer produce tomatoes. These growers did not have the economic resources to employ the management tactics used by the large growers. However, small-plot production is characteristic of the tropics. These growers could be helped by the availability of resistant, open-pollinated cultivars and by the development of appropriate cultural practices, which would reduce both whiteflies and virus. The management of geminiviruses by numerous growers with small plots and limited resources, in the context of year-round tomato production, is the greatest challenge for geminivirus management.

\section{Conclusion}

This article summarizes the dynamic changes in the whitefly-transmitted geminiviruses that infect tomato in the Americas. Geminiviruses have been an emerging disease threat for decades; however, in the last decade the disease rate has increased to an alarming degree (5). In the 1970s, only CdTV, ToYMV, and TGMV were known to infect tomatoes, and there were few oral reports of similar problems from other countries. By 1996, approximately 17 species of geminiviruses, plus new strains, had been reported. Numerous other viruses were reported, but their taxonomic status awaits clarification. Reports of escalating yield losses have become more frequent as well. Whitefly-transmitted geminiviruses in tomatoes have become widespread geographically, resulting in devastating epidemics throughout the Americas. In addition to emergence, recent evolution may account for the appearance of some of these viruses.

It is apparent that the geographic range of individual geminiviruses is expanding. This is true for CdTV, PHV, and TPV in Mexico, and PYMV and TYLCV in the Caribbean $(56,60,66,68,74,97)$. Although the means of expansion are varied, the primary reason is the introduction of a new vector, $B$. tabaci biotype $\mathrm{B}$, which can exploit solanaceous hosts for both feeding and reproduction. As this whitefly has spread through the Western Hemisphere, new geminiviruses have appeared in its wake. Another factor that has contributed to the dissemination of these viruses is the long-distance movement of transplants of tomato and other solanaceous virus hosts. Often, tomato transplants infected with a geminivirus do not show symptoms, leading to the erroneous conclusion by growers that their transplants are virus-free. This is most likely the method by which the geographic range of TYLCV expanded to include three countries in the Caribbean, and may account for some of the geographic expansion of geminiviruses within Mexico. Although short-range migration of the B biotype has been described, no studies on long-distance movement have been reported (20). It can be speculated that hurricanes or prevailing winds may move viruliferous whiteflies long distances over water. Circumstantial evidence for this possibility includes the observation that the same strain of PYMV, with few sequence variations, can be found in islands $600 \mathrm{~km}$ apart in the Caribbean, the appearance of TYLCV in Jamaica within a year or so of its appearance in the Dominican Republic, and the appearance of bean golden mosaic virus in southern Florida within 2 months after Hurricane Andrew (10,56,66).

Many of the geminiviruses reported in the past decade were previously unknown, and their origins are subject to much speculation. Geminiviruses often occur in mixed infections in tomato. Mixtures of DNA components (i.e., an A and B component from one virus and an A component from another virus) have been found in samples from field plants $(43,64,97)$. Such complexes are not unique to tomato and have been reported in other vegetable crops $(17,37,72)$. These complexes may play an important role in the evolution of virus strains and species. Pseudorecombination 
(the exchange of DNA components) and recombination (the exchange of DNA between DNA components) of geminiviruses have been demonstrated in the laboratory $(39,64)$. Recently, a new highly virulent strain of African cassava mosaic virus (ACMV) in eastern Africa was found to be a recombinant of two previously described strains of ACMV (103). These laboratory and field data on mechanisms of variability fuel the speculation that some of the tomato geminiviruses may be recently evolved viruses that are able to exploit tomatoes.

Successful management of whiteflytransmitted geminiviruses in tomatoes has not been achieved in most areas. It can be anticipated that for most of these viruses, management strategies will need to be multi-component in nature and based on a thorough understanding of the pathosystems involved. The cornerstone of crop protection will be the use of resistant cultivars, so the development of host resistance in both fresh-market and processing tomato is vital. However, rational breeding programs depend on a thorough knowledge of the targeted pathogens. Thus, geminivirus characterization is a critical first step to setting up effective breeding programs. Deployment of resistant cultivars will have to be accompanied by vector management schemes, which currently rely almost entirely on chemical insecticides. Unfortunately, whitefly populations are already developing resistance to the widely used chemical imidacloprid, as they have done with many other insecticides. The lack of available vector management strategies is related in part to a shortage of knowledge regarding the epidemiology of geminiviruses. In consideration of the alarming rate with which new geminiviruses are emerging in tomato, there is an urgent need to develop appropriate conceptual frameworks. It is probable that only through this multi-component approach will economically and environmentally sound approaches be developed for the successful management of these viruses.

\section{Acknowledgments}

We thank the Danish International Development Agency for support (P. Anderson); Justine Klass of the CIAT GIS Unit for preparation of the maps; R. J. McGovern and F. J. Morales for critical reviews; and J. K. Brown, L. Hilje, P. Himmel, R. Rivera-Bustamente, and R. C. de Uzcátegui for photographs. Florida Agricultural Experiment Station Journal Series No. R-05983.

\section{Literature Cited}

1. Abouzid, A. M., Polston, J. E., and Hiebert, E. 1992. The nucleotide sequence of tomato mottle virus, a new geminivirus isolated from tomato in Florida. J. Gen. Virol. 73:3225-3229.

2. Allen, J. C., Brewster, C. C., Paris, J. F., Riley, D. G., and Summers, C. G. 1995. Spatiotemporal modeling of whitefly dynamics in a regional cropping system using satellite data. Pages 111-124 in: Bemisia: 1995, Taxonomy, Biology, Damage, Control and Management. Intercept, Hants, Andover, Eng.

3. Alvarez, P. A., and Abud-Antún, A. J. 1995. Reporte de República Dominicana. CEIBA (Honduras) 36:39-47.

4. Anderson, P. K. 1993. Un modelo para la investagacion en mosca blanca, Bemisia tabaci (Gennadius). Pages 27-33 in: Las moscas blancas (Homoptera: Aleyrodidae) en America Central y el Caribe. L. Hilje and O. Arboleda, eds. CATIE, Turrialba, Costa Rica (Serie Tecnica. Inf. Tech. No. 205).

5. Anderson, P. K., and Morales, F. J. 1994. The emergence of new plant diseases: The case of insect-transmitted plant viruses. Ann. N.Y. Acad. Sci. 740:181-194.

6. Bedford, I. D., Briddon, R. W., Brown, J. K., Rosell, R. C., and Markham, P. G. 1994. Geminivirus transmission and biological characterization of Bemisia tabaci (Gennadius) biotypes from different geographic regions. Ann. Appl. Biol. 125:311-325.

7. Bethke, J. A., Paine, T. D., and Nuessly, G. S. 1991. Comparative biology, morphometrics, and development of two populations of Bemisia tabaci (Homoptera: Aleyrodidae) on cotton and poinsettia. Ann. Ent. Soc. Am. 84:407-411

8. Bezerra, I. C., Ribeiro, S. G., de D'Avila, A. C., and Giordano, L. B. 1996. Survey of geminivirus infection in tomato producing areas in the Federal District. (Abstr.) Proc. Meet. Brazil. Soc. Virol., 8th. Sao Lourenço, MG. p. 289.

9. Bird, J., Brown, J. K., Sosa, M., and Nazario, G. M. 1995. Reporte de Puerto Rico. CEIBA (Honduras) 36:37-38.

10. Blair, M. W., Bassett, M. J., Abouzid, A. M., Hiebert, E., Polston, J. E., McMillan, R. T., Jr., Graves, W., and Lamberts, M. 1995. Occurrence of bean golden mosaic virus in Florida. Plant Dis. 79:529-533.

11. Brown, J. K. 1993. Evaluacion critica sobre los biotypos de mosca blanca en America, de 1989 a 1992. Pages 1-9 in: Las Moscas Blancas (Homoptera: Aleyrodidae) en America Central y El Caribe. L. Hilje and O. Arboleada, eds. CATIE, Turrialba, Costa Rica.

12. Brown, J. K. 1994. Current status of Bemisia tabaci as a plant and virus vector in agroecosystems worldwide. FAO Plant Prot. Bull. 41:3-32.

13. Brown, J. K., Bird, J., Banks, G., Sosa, M., Kiesler, K., Cabrera, I., and Fornaris, G. 1995. First report of an epidemic in tomato caused by two whitefly-transmitted geminiviruses in Puerto Rico. Plant Dis. 79:1250.

14. Brown, J. K., Frohlich, D. R., and Rosell, R. C. 1995. The sweetpotato or silverleaf whiteflies: Biotypes of Bemisia tabaci or a species complex? Annu. Rev. Entomol. 40:511-534.

15. Brown, J. K., Idris, A. M., and Fletcher, D. C. 1993. Sinaloa tomato leaf curl virus, a newly described geminivirus of tomato and pepper in west coastal Mexico. Plant Dis. 77:1262.

16. Brown, J. K., Lastra, R., and Bird, J. 1992. First documentation of whitefly-transmitted geminiviruses causing widespread disease in cotton, tobacco, and tomato in Dominican Republic and tomato in Puerto Rico. (Abstr.) Phytopathology 82:607.

17. Brown, J. K., and Nelson, M. R. 1988. Transmission, host range, and virus-vector relationships of chino del tomate, a whiteflytransmitted geminivirus from Sinaloa, Mexico. Plant Dis. 72:866-869.

18. Brown, J. K., and Poulos, B. T. 1990. Serrano golden mosaic virus: A newly identified whitefly-transmitted geminivirus of pepper and tomato in the United States and Mexico. Plant Dis. 74:720.

19. Byrne, D. N., Bellows, J., Thomas S., and Parrella, M. P. 1990. Whiteflies in agricultural systems. Pages 227-262 in: Whiteflies: Their Bionomics, Pest Status, and Management. D. Gerling, ed. Intercept, Andover, Eng.

20. Byrne, D. N., Rathman, R. J., Orum, T. V., and Palumbo, J. C. 1996. Localized migration and dispersal by the sweet potato whitefly, Bemisia tabaci. Oecologia 105:320-328.

21. Caballero, R., and Rueda, A. 1993. Las moscas blancas en Honduras. Pages 50-53 in: Las Moscas Blancas (Homoptera: Aleyrodidae) en America Central y El Caribe. L. Hilje and O. Arboleada, eds. CATIE, Turrialba, Costa Rica.

22. Cahill, M., Gorman, K., Kay, S., and Denholm, I. 1996. Baseline determination and detection of resistance to imidacloprid in Bemisia tabaci (Homoptera: Aleyrodidae). Bull. Entomol. Res. 86:343-349.

23. Calixto, M., Vazques, L. L., and Mateo, A. 1995. Reporte de Cuba. CEIBA (Honduras) 36:7-8.

24. Cancino, M., Hiebert, E., Purcifull, D., Polston, J. E., and Morales, F. J. 1995. Monoclonal antibody with broad specificity to whitefly-transmitted geminiviruses. Phytopathology 85:484-501.

25. Christie, R. G., Ko, N.-J., Falk, B. W., Hiebert, E., Lastra, R., Bird, J., and Kim, K. S 1986. Light microscopy of geminivirus-induced nuclear inclusion bodies. Phytopathology 76:124-126.

26. Cohen, S., and Antignus, Y. 1994. Tomato yellow leaf curl virus, a whitefly-borne geminivirus of tomatoes. Adv. Dis. Vector Res. 10:259-288.

27. Coutts, R. H. A., Coffin, R. S., Roberts, E. J. F., and Hamilton, W. D. O. 1991. The nucleotide sequence of the infectious cloned DNA components of potato yellow mosaic virus. J. Gen. Virol. 72:1515-1520.

28. Csizinszky, A. A., Schuster, D. J., and Kring, J. B. 1995. Color mulches influence yield and insect pest populations in tomatoes. $\mathrm{J}$ Am. Soc. Hortic. Sci. 120:778-784.

29. Dardon, D. E. 1993. Las moscas blancas en Guatemala. Pages 38-41 in: Las Moscas Blancas (Homoptera: Aleyrodidae) en America Central y El Caribe. L. Hilje and O. Arboleada, eds. CATIE, Turrialba, Costa Rica.

30. Debrot, E., and Dao, H. y. F. 1963. Nota preliminar sobre un "mosaico amarillento del tomate" in Venezuela. Agron. Trop. 13:33-41.

31. Diaz, R., and Bierly, F. 1995. Efecto de la infeccion por virosis transmitido por mosca blanca en diferentes fechas despues del transplante sobre la produccion de tomate $y$ chile habanero. CEIBA (Honduras) 36:111.

32. Faria, J. C., Souza-Dias, J. A. C., Slack, S. A., and Maxwell, D. P. 1997. A new geminivirus associated with tomato in the State of São Paulo, Brazil. Plant Dis. 81:423.

33. Flores, E., and Silberschmidt, K. 1958. Relations between insect and host plant in transmission experiments with infectious chlorosis of Malvaceae. Anais Acad. Brasil. Ciências 30:535-569.

34. Flores, E., Silberschmidt, K., and Kramer, M. 1960. Observacoes de "clorose infecciosa" das malvaceas en tomateiros do campo. O Biologico 26:65-69.

35. França, F. H., Villas-Bôas, G. L., and Castelo Branco, M. 1996. Ocorrência de Bemisia argentifolii Bellows \& Perring (Homoptera: Aleyrodidae) no Distrito Federal. Anais Soc. Entomol. Brasil 25:369-372.

36. Gallegos, H. M. L. 1978. Enchinamiento del tomate (chino disease of tomato). Page 119 
in: Enfermedades de cultivos en el estado de Sinaloa. Secretaria Agric. Recursos Hidraulicos, Sinaloa, Mexico.

37. Garzón-Tizado, J. A., Torres-Pacheco, I., Ascencio-Ibañez, J. T., Herrera-Estrella, L., and Rivera-Bustamante, R. F. 1993. Inoculation of peppers with infectious clones of a new geminivirus by a biolistic procedure. Phytopathology 83:514-521.

38. Gilbertson, R. L., Hidayat, S. H., Martinez, R. T., Leong, S. A., Fona, J. C., Morales, F. J., and Maxwell, D. P. 1991. Differentiation of bean infecting geminiviruses by nucleic acid hybridization probes and aspects of bean golden mosaic virus in Brazil. Plant Dis. 75:336-342.

39. Gilbertson, R. L., Paplomatas, E. J., Grieco, P. D., Patel, V. P., and Maxwell, D. P. 1993. Agroinfection of bean, tobacco, and tomato with two bipartite geminiviruses isolated from tomato. Phytopathology 83:1350.

40. Giordano, L. B., Bezerra, I. C., Ribeiro, S. G. and D'Avila, A. C. 1996. Breeding tomatoes (Lycopersicon esculentum Mill.) for resistance to whitefly-transmitted geminiviruses. Int. Symp. Trop. Tomato Dis., Recife, PE, Brazil, 1st. (Conf. summary)

41. Givord, L., Fargette, D., Kounounguissa, B., Thouvenel, J. C., Walter, B., and van Regenmortel, M. H. V. 1994. Detection of geminiviruses from tropical countries by a double monoclonal antibody ELISA using antibodies to African cassava mosaic virus. Agronomie 14:327-333.

42. González A., G., and Valdés R., S. 1995. Virus del encrespamiento amarillo de las hojas del tomate (TYLCV) en Cuba. CEIBA (Honduras) 36:103.

43. Guzman, P., Arredondo, C. R., Emmatty, D., Portillo, R. J., and Gilbertson, R. L. 1997. Partial characterization of two whiteflytransmitted geminiviruses infecting tomatoes in Venezuela. Plant Dis. 81:312.

44. Hamilton, W. D. O., Sanders, R. C., Coutts, R. H. A., and Buck, K. W. 1981. Characterization of tomato golden mosaic virus as a geminivirus. FEMS Microbiol. Lett. 11:263267.

45. Hiebert, E., Abouzid, A. M., and Polston, J. E. 1995. Whitefly-transmitted geminiviruses. Pages 277-288 in: Bemisia: Taxonomy, Biology, Damage, Control and Management. D. Gerling and R. T. Mayer, eds. Intercept, Andover, Eng.

46. Hilje, L., Lastra, R., Zoebisch, T., Calvo, G., Segura, L., Barrantes, L., Alpizar, D., and Armador, R. 1993. Las moscas blancas en Costa Rica. Pages 58-63 in: Las Moscas Blancas (Homoptera: Aleyrodidae) en America Central y El Caribe. L. Hilje and O. Arboleada, eds. CATIE, Turrialba, Costa Rica.

47. Hilje, L., and Montes, P. L. 1995. Reporte de Costa Rica. CEIBA (Honduras) 36:157-162.

48. Hostachy, B., and Allex, D. 1993. Un géminivirus de la tomate transmis par $\mathrm{Be}$ misia tabaci. Phytoma No. 456:24-28.

49. Hostachy, B., and Allex, D. 1994. Géminivirus de la tomate du nouveau. Phytoma 457:4.

50. Hou, Y.-M., Garrido-Ramirez, E. R., Stingley, S., Guzman, P., and Gilbertson, R. L. 1996. Characterization of the infectious clones of the Sinaloa strain of pepper huasteco geminivirus. (Abstr.) Phytopathology 86:S43

51. Kring, J. B., Schuster, D. J., Price, J. F., and Simone, G. W. 1991. Sweetpotato whiteflyvectored geminivirus on tomato in Florida. Plant Dis. 75:1186.

52. Lastra, J. R., and de Uzcátegui, R. C. 1975. Viruses affecting tomatoes in Venezuela. Phytopathol. Z. 84:253-258.

53. Leiss, K., Sanz, N. T., and Sosa, O. 1995. Reporte de Belize. CEIBA (Honduras)
36(1):5-6

54. Lourenço, A. L. 1997. Perspectivas de danos e controle de Bemisia argentifolii no Brasil. (Abstr.) 16o Congresso Brasileiro de Entomologia, Salvador, BA, Brasil. pp. 8-9.

55. Matyis, J. C., Silva, D. M., Oliveira, A. R., and Costa, A. S. 1975. Purificaçao e morfologia do vírus do mosaico dourado do tomateiro. Summa Phytopathol. 1:267-274.

56. McGlashan, D., Polston, J. E., and Bois, D. 1994. Tomato yellow leaf curl geminivirus in Jamaica. Plant Dis. 78:1219.

57. McGovern, R. J., Polston, J. E., Danyluk, G. M., Hiebert, E., and Stansly, P. A. 1994 Identification of a weed host of tomato mottle geminivirus in Florida. Plant Dis. 78:1102-1106

58. Melo, P. C. T. 1992. Mosca branca ameaça produçao de hortaliças. Asgrow do Brasil Sementes Ltda., Campinas, SP, Brazil. Tech. Bull.

59. Meneses, R., de Uzcátegui, R., and Lastra, R. 1989. El virus mosaico amarillo del tomate en Costa Rica. Resumenes XXIX Reunion APS-CD, Cali, Colombia. p. 78.

60. Nakhla, M. K., Maxwell, D. P., Martinez, R. T., Carvalho, M. G., and Gilbertson, R. L. 1994. Occurrence of the eastern Mediterranean strain of tomato yellow leaf curl geminivirus in the Dominican Republic. (Abstr.) Phytopathology 84:1072.

61. Nakhla, M. K., Maxwell, M. D., Hidayat, S. H., Lange, D. R., Loniello, A. O., Rojas, M. R., Maxwell, D. P., Kitajima, E. W., Rojas, A., Anderson, P., and Gilbertson, R. L. 1994. Two geminiviruses associated with tomatoes in Central America. (Abstr.) Phytopathology $84: 1155$.

62. O'Doherty, R. 1995. Report of a geminivirus disease complex associated with B-biotype of sweetpotato whitefly in Belize, Central America. Plant Dis. 79:1250.

63. Padidam, M., Beachy, R. N., and Fauquet, C. M. 1995. Classification and identification of geminiviruses using sequence comparisons. J. Gen. Virol. 76:249-263.

64. Paplomatas, E. J., Patel, V. P., Hou, Y.-M., Noueiry, A. O., and Gilbertson, R. L. 1994. Molecular characterization of a new saptransmissible bipartite genome geminivirus infecting tomatoes in Mexico. Phytopathology 84:1215-1224.

65. Perring, T. M., Cooper, A. D., Rodriguez, R. J., Farrar, C. A., and Bellows, T. S. 1993. Identification of a whitefly species by genomic and behavioral studies. Science 259:74-77.

66. Polston, J. E., Bois, D., Ano, G., Poliakoff, F., and Urbino, C. Occurrence of a strain of potato yellow mosaic geminivirus in tomato in the eastern Caribbean. Plant Dis. In press.

67. Polston, J. E., Bois, D., Keinath, A. P., and Chellemi, D. O. 1995. Occurrence of tomato mottle geminivirus in South Carolina, Tennessee, and Virginia. Plant Dis. 79:539.

68. Polston, J. E., Bois, D., Serra, C. A., and Concepcion, S. 1994. First report of a tomato yellow leaf curl-like geminivirus from tomato in the Western Hemisphere. Plant Dis. 78:831.

69. Polston, J. E., Chellemi, D. O., Schuster, D. J., McGovern, R. J., and Stansly, P. A. 1996. Spatial and temporal dynamics of tomato mottle geminivirus and Bemisia tabaci in Florida tomato fields. Plant Dis. 80:10221028

70. Polston, J. E., Gilreath, P., Schuster, D. J., and Chellemi, D. O. 1994. Recent developments in tomato geminiviruses: A new virus and a new pesticide. Pages 65-76 in: Proc. Fla. Tomato Inst. C. S. Vavrina, ed. University of Florida, IFAS, Vegetable Crops Special Series, PRO-105.
71. Polston, J. E., Hiebert, E., McGovern, R. J. Stansly, P. A., and Schuster, D. J. 1993. Host range of tomato mottle virus, a new geminivirus infecting tomato in Florida. Plant Dis. 77:1181-1184.

72. Polston, J. E., Perring, T. M., and Dodds, J. A. 1989. Nucleic acid probes for detection and strain discrimination of cucurbit geminiviruses. Phytopathology 79:1123-1126.

73. Polston, J. E., Schuster, D. J., and Chellemi, D. O. 1993. Advances in the management of tomato mottle geminivirus. Pages 69-76 in: Proc. Fla. Tomato Inst. C. S. Vavrina, ed. University of Florida, IFAS, Vegetable Crops Special Series, PRO-105.

74. Ramos, P. L., Guerra, O., Dorestes, V., Ramirez, N., Rivera-Bustamante, R., and Oramas, P. 1996. Detection of TYLCV in Cuba. Plant Dis. 80:1208.

75. Ramos, P. L., Guerra, O., Peral, R., Oramas, P., Guevara, R. G., and Rivera-Bustamante, R. 1997. Taino tomato mottle virus, a new bipartite geminivirus from Cuba. Plant Dis. $81: 1095$

76. Rezende, E. A., Filgueira, F. A. R., Zerbini, F. M., Maciel-Zambolim, E., Fernandes, J. J., and Gilbertson, R. L. 1996. Tomato infected with geminivirus under greenhouse conditions at Uberlândia-MG, Brazil. (Abstr.) Fitopatol. Brasil. 21:424

77. Ribeiro, S. G., Bezerra, I. C., Lima, M. F., de D'Avila, A. V., and Giordano, L. B. 1996. Occurrence of geminivirus in tomato plants in Bahia. (Abstr.) Proc. Meet. Brazil. Soc. Virol., 8th. São Lourenço, MG. p. 290.

78. Ribeiro, S. G., Mello, L. V., Boiteux, L. S., Kitajima, E. W., and Faria, J. C. 1994. Tomato infection by a geminivirus in the Federal District, Brazil. (Abstr.) Fitopatol. Brasil. 19:330.

79. Rivera, R. 1995. Recombinacion de geminivirus y sus implicaciones en la agricultura. CEIBA (Honduras) 36:99-102.

80. Roberts, E. J. F., Buck, K. W., and Coutts, R. H. A. 1986. A new geminivirus infecting potatoes in Venezuela. Plant Dis. 70:603.

81. Roberts, E. J. F., Buck, K. W., and Coutts, R. H. A. 1988. Characterization of potato yellow mosaic virus as a geminivirus with a bipartite genome. Intervirology 29:162-169.

82. Rojas, M. R., Gilbertson, R. L., Russell, D. R., and Maxwell, D. P. 1993. Use of degenerate primers in the polymerase chain reaction to detect whitefly-transmitted geminiviruses. Plant Dis. 77:340-347.

83. Rosset, P. M. 1986. Ecological and economic aspects of pest management and polycultures of tomatoes in Central America. Ph.D. thesis. University of Michigan, Ann Arbor.

84. Rybicki, E. P. 1994. A phylogenetic and evolutionary justification for three genera of Geminiviridae. Arch. Virol. 139:49-77.

85. Salas, J., and Mendoza, O. 1995. Reporte de Venezuela. CEIBA 36(1):49-50.

86. Salguero, R. 1994. Analisis del complejo mosca blanca-virosis en tomate. Pages 16-22 in: Memorias, III Taller Centroamericano y del Caribe sobre mosca blanca. Ed. Mata, M., Dardon, D. and Salguero, V. Antigua, Guatemala.

87. Sánchez, A. J., Sánchez, G. H., De Avila, D H., Rodriguez, L. G., and Dano, R. P. 1996. Campana contra la mosquita blanca en la region Lagunera, ciclo 1996. Memorias V Taller Latinoamericano sobre Moscas Blancas y Geminivirus. Departamento de Parasitologia, Universidad Autonoma Chapingo. p. 228.

88. Sánchez, V., Frías, G., Aguirre, L., Bravo, L., Cotéz, E., Quezada, J., Ruiz, R., Hernández, M., Rangel, U., Garzón, J., Rivera-Bustamante, R., Gilbertson, R., and Rojas, M. 1996. Agro ecology of a whitefly- 
transmitted geminivirus in an arid and isolated Serrano pepper growing region in northeastern Mexico. (Abstr.) Phytopathology $86:$ S 117 .

89. Schuster, D. J. 1992. Report. Bemisia Newsl. No. 5:1-3.

90. Schuster, D. J., Mueller, T. F., Kring, J. B., and Price, J. F. 1990. Relationship of the sweetpotato whitefly to a new tomato fruit disorder in Florida. HortScience 25:16181620

91. Schuster, D. J., Stansly, P. A., Dean , D. G., Polston, J. E., and Swanson, G. S. 1993. Progress toward a more sustainable pest management program for tomato. Pages 77106 in: Proc. Fla. Tomato Inst. C. S. Vavrina, ed. University of Florida, IFAS, Vegetable Crops Special Series, PRO-105.

92. Scott, J. W., Stevens, M. R., Barten, J. H. M., Thome, C. H., Polston, J. E., Schuster, D. J., and Serra, C. A. 1995. Introgression of resistance to whitefly-transmitted geminiviruses from Lycopersicon chilense to tomato. Pages 357-367 in: Bemisia: Taxonomy, Biology, Damage, Control and Management. D. Gerling and R. T. Mayer, eds. Intercept, Andover, Eng.

93. Serra, C. A., Polston, J. E., Concepcion, S., Ortiz, M., Nunez, J. B., and Benoit, P. F. 1995. Host range of TYLCV-DR and its vectors and strategies to reduce damages in northwestern Dominican Republic. (Abstr.) Page 15 in: Proc. Symp. Biol. Mol. Biol. Epidemiol. Geminiviruses.

94. Serra, C. A., and Schmutterer, H. 1993. Control of sweetpotato whitefly Bemisia tabaci Genn. with neem-seed extracts in tomato fields in the Dominican Republic. (In German, English abstract.) Entomologen Tagung 1991, Vienna, Austria, Mitt. Dt. Ges. Allg. Angew. Ent. 8:795-801.

95. Serrano, L., Sermeno, J. M., and Larios, J. 1993. Las moscas blancas en El Salvador. Pages 42-49 in: Las Moscas Blancas (Homoptera: Aleyrodidae) en America Central y El Caribe. L. Hilje and O. Arboleada, eds. CATIE, Turrialba, Costa Rica.

96. Stenger, D. C., Duffus, J. E., and Villalon, B. 1990. Biological and genomic properties of a geminivirus isolated from pepper. Phytopathology 80:704-709.

97. Torres-Pacheco, I., Garzón-Tiznado, J. A., Brown, J. K., Becerra-Flora, A., and RiveraBustamante, R. F. 1996. Detection and distribution of geminiviruses in Mexico and the southern United States. Phytopathology 86:1186-1192.

98. Torres-Pacheco, I., Garzón-Tiznado, J. A., Herrera-Estrella, L., and Rivera-Bustamante, R. F. 1993. Complete nucleotide sequence of pepper huasteco virus: Analysis and comparison with bipartite geminiviruses. J. Gen. Virol. 74:2225-2231.

99. Uzcátegui, R. C. de, and Lastra, R. 1978. Transmission and physical properties of the causal agent of mosaico amarillo del tomate (tomato yellow mosaic). Phytopathology 68:985-988

100. Varela, G. 1995. Reporte de Nicaragua. CEIBA (Honduras) 36:25-27.

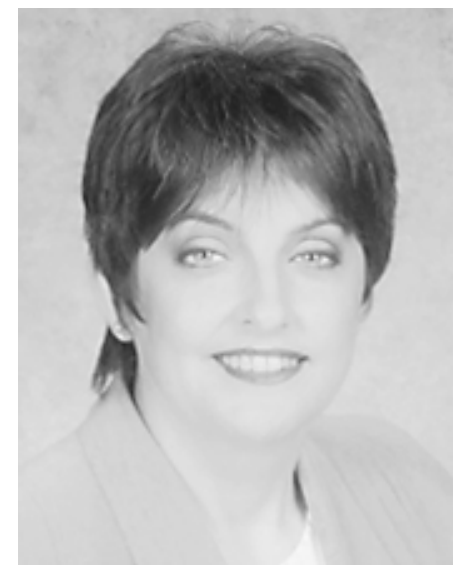

Jane E. Polston

Dr. Polston is an associate professor at the University of Florida located at the Gulf Coast Research and Education Center at Bradenton, Florida. She received a B.S. in horticultural sciences in 1976 and an M.S. in 1978 from Virginia Tech. Dr. Polston worked with the INTSOY (International Soybean) program of the University of Illinois from 1980 to 1984 on geminivirus and potyvirus diseases of soybeans. She received her Ph.D. in 1988 from the Department of Plant Pathology of the University of California, Riverside, with dissertation research on a geminivirus of cucurbits. Dr. Polston joined the faculty of the University of Florida in 1991. Her research responsibilities include the identification and management of viral diseases of vegetable and ornamental crops. Since coming to Florida, her research has focused on the identification, characterization, and management of geminiviruses, primarily in tomato and bean.

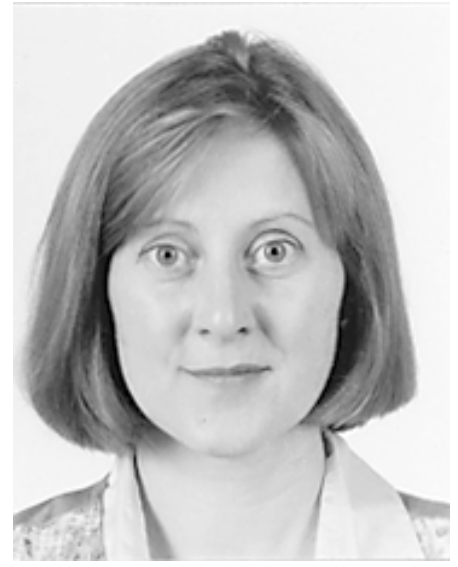

Pamela K. Anderson

Dr. Anderson is a senior scientist at the International Center for Tropical Agriculture (CIAT) in Cali, Colombia, and the coordinator for the CGIAR Whitefly IPM Project. She received her B.A. degree in biology, with a concentration in theoretical ecology, from Northwestern University, Evanston, Illinois. In 1982, she received an M.Sc. in entomology, with a concentration in insect ecology, from the University of Illinois, Champaign-Urbana. In 1984, she received a second M.Sc. degree in population sciences (concentration in human ecology) from Harvard. In 1991, she received her D.Sc. degree, also in population sciences, from Harvard, with thesis research on the epidemiology of insect-transmitted plant pathogens. Dr. Anderson is a research consultant to the Department of Population and Health Sciences at Harvard, where she works on emerging diseases. She is an advisor to the Federation of American Scientists' Project for Monitoring Emerging Diseases (ProMED); she moderates the ProMEDmail plant conference and is a member of the FAS International Plant Threats Working Group.
101. Zachrisson, B., and Poveda, J. 1993. Las moscas blanca en Panama. Pages 64-66 in: Las Moscas Blancas (Homoptera: Aleyrodidae) en America Central y El Caribe. L. Hilje and O. Arboleada, eds. CATIE, Turrialba, Costa Rica.

102. Zerbini, F. M., Zambolim, E. M., Carrijo, I. V., and Gilbertson, R. L. 1996. A new bipartite geminivirus infecting tomatoes in Minas
Gerais State, Brazil. (Abstr.) Phytopathology 86:S1

103. Zhou, X., Liu, Y., Calvert, L., Munoz, C., Otim-Nape, G. W., Robinson, D. J., and Harrison, B. D. 1997. Evidence that DNA-A of a geminivirus associated with severe cassava mosaic disease in Uganda has arisen by interspecific recombination. J. Gen. Virol. 78:2101-2111 